\title{
Microscopic Aspects of Silicon-Mediated Rice Resistance to Leaf Scald
}

\author{
Leonardo Araujo, Rayane Silva Paschoalino, and Fabrício Ávila Rodrigues
}

Universidade Federal de Viçosa, Departamento de Fitopatologia, Laboratório da Interação Planta-Patógeno, Viçosa, Minas Gerais State, CEP 36570-900, Brazil.

Accepted for publication 29 July 2015.

\begin{abstract}
Araujo, L., Paschoalino, R. S., and Rodrigues, F. A. 2016. Microscopic aspects of silicon-mediated rice resistance to leaf scald. Phytopathology 106:132-141.

This study investigated the effect of silicon $(\mathrm{Si})$ on the potentiation of rice resistance against leaf scald at the microscopic level. Rice plants ('Primavera') were grown in a nutrient solution containing $0(-\mathrm{Si})$ or $2 \mathrm{mM}(+\mathrm{Si}) \mathrm{Si}$. The foliar Si concentration of the $+\mathrm{Si}$ plants $(3.6 \mathrm{dag} / \mathrm{kg})$ increased in comparison with the -Si plants $(0.3 \mathrm{dag} / \mathrm{kg})$. An X-ray microanalysis revealed that the leaf tissue of + Si plants infected with Microdochium oryzae had higher peaks and deposition of insoluble $\mathrm{Si}$ than that of $-\mathrm{Si}$ plants. The high foliar $\mathrm{Si}$ concentration for the $+\mathrm{Si}$ plants reduced the expansion of leaf scald lesions. Scanning electron microscopy revealed that fungal hyphae and appressoriumlike structures of $M$. oryzae were more abundant in the leaf surface of $-\mathrm{Si}$
\end{abstract}

ABSTRACT

Leaf scald, which is caused by Monographella albescens (Thümen) Parkinson and Sivanesan C. Booth (anamorphic form Microdochium oryzae (Hashioka and Yokogi) Samuels and Hallett), is one of the major diseases affecting rice worldwide and can cause yield losses of up to 30\% (Filippi and Prabhu 2005; Ou 1985). Conidia of $M$. oryzae germinate on the adaxial leaf surface of rice plants and produce appressorium-like structures upon contact with the stomata, from which substomatal hyphae grow profusely into the intercellular spaces to colonize the mesophyll cells (Bedendo and Prabhu 2005; Filippi and Prabhu 2005). The conidiophores grow out from the stomata and produce conidia beginning at $72 \mathrm{~h}$ after fungal penetration takes place (Bedendo and Prabhu 2005; Filippi and Prabhu 2005). The symptoms of leaf scald include zonate or oblong olive-colored lesions with light brown halos lacking well-defined margins on the leaf tips or edges (Bedendo and Prabhu 2005; Filippi and Prabhu 2005; Ou 1985). The most favorable conditions for the occurrence of leaf scald epidemics are periods of intense rain and prolonged foliar dew, temperatures ranging from 24 to $28^{\circ} \mathrm{C}$, close spacing, and excess nitrogen (Bedendo and Prabhu 2005; Filippi and Prabhu 2005; Ou 1985). Leaf scald has been managed by avoiding excess nitrogenous fertilizer, using cultivars with high levels of basal resistance, and seed treatments using fungicides or their foliar spray (Araújo et al. 2001; Bedendo and Prabhu 2005; Filippi and Prabhu 2005; Ou 1985).

Finding alternative methods for leaf scald management is necessary to avoid the yield losses caused by this disease (Bedendo and Prabhu 2005; Filippi and Prabhu 2005; Ou 1985). In light of these concerns, the supply of silicon $(\mathrm{Si})$ to crops of economic importance shows promise as an environmentally friendly choice considering its potential to decrease the intensities of important root and foliar diseases (Datnoff et al. 2007). The Si-mediated rice

Corresponding author: F. A. Rodrigues; E-mail address: fabricio@ufv.br

http://dx.doi.org/10.1094/PHYTO-04-15-0109-R

(C) 2016 The American Phytopathological Society plants relative to $+\mathrm{Si}$ plants. At both histopathological and ultrastructural levels, fungal hyphae grew abundantly into the leaf tissue of $-\mathrm{Si}$ plants. By contrast, rice cell walls were rarely degraded and fungal hyphae were often surrounded by amorphous granular material in the leaf tissue of $+\mathrm{Si}$ plants. Conidiophores emerged from stomata $36 \mathrm{~h}$ after fungal penetration, and conidia were noticed inside the leaf tissue of the -Si plants in great abundance. The collective results of the present study showed a high concentration and deposition of $\mathrm{Si}$ and a considerable deposition of phenolic-like compounds in the leaf tissue of $+\mathrm{Si}$ plants. These results indicate that the potentiation of the phenylpropanoid pathway in these plants supplied with $\mathrm{Si}$ was favorable for the increase in rice resistance to leaf scald.

Additional keywords: host defense responses, Monographella albescens, Oryza sativa. resistance to blast has been attributed to an increase in the density of the long and short silicate cells in the leaf epidermis or the existence of a thick silica layer below the cuticle that forms a physical barrier that prevents or slows fungal penetration (Kim et al. 2002; Yoshida et al. 1962). Increases in the concentrations of phenolics, lignins, and phytoalexins, an enhanced activity of defense-related enzymes and the fast and strong transcription of genes that are related to host defense against pathogens are the reported biochemical mechanisms that are potentiated by $\mathrm{Si}$ in plants infected by pathogens (Fortunato et al. 2014; Rodrigues et al. 2003, 2004, 2005; Tatagiba et al. 2014).

At the microscopic level, several studies have demonstrated the importance of $\mathrm{Si}$ in enhancing the resistance of plants to pathogens (Bélanger et al. 2003; Domiciano et al. 2010; Fortunato et al. 2014; Hayasaka et al. 2008; Kim et al. 2002; Koga et al. 1988; Rodrigues et al. 2003, 2005). Koga et al. (1988) using fluorescence microscopy and X-ray microanalysis observed that the accumulation of insoluble $\mathrm{Si}$ in the epidermal cells of barley plants infected with Blumeria graminis f. sp. hordei was associated with an increase in the autofluorescence intensity, which indirectly indicated the presence of phenolic-like compounds. Rodrigues et al. (2003) observed that in the rice leaf tissue of plants supplied with $\mathrm{Si}$, there was an abundant occurrence of empty fungal hyphae of Pyricularia oryzae surrounded by phenolic-like compounds that were further identified as momilactones A and B (Rodrigues et al. 2004).

The present study aimed to investigate the effect of $\mathrm{Si}$ on the potentiation of rice resistance against leaf scald considering that studies examining how this element is involved in the host defense mechanisms at the microscopic level are, to the best of the authors' knowledge, lacking in the literature.

\section{MATERIALS AND METHODS}

Nutrient solution preparation and plant growth. The nutrient solution used in the present study was prepared based on 
Hoagland and Arnon (1950) and consisted of $1.0 \mathrm{mM} \mathrm{KNO}_{3}$, $0.25 \mathrm{mM} \mathrm{NH}_{4} \mathrm{H}_{2} \mathrm{PO}_{4}, 0.1 \mathrm{mM} \mathrm{NH} \mathrm{N}_{4} \mathrm{Cl}, 0.5 \mathrm{mM} \mathrm{MgSO}{ }_{4} \cdot 7 \mathrm{H}_{2} \mathrm{O}$, $1.0 \mathrm{mM} \mathrm{Ca}\left(\mathrm{NO}_{3}\right)_{2}, 0.30 \mu \mathrm{M} \mathrm{CuSO}_{4} \cdot 5 \mathrm{H}_{2} \mathrm{O}, 0.33 \mu \mathrm{M} \mathrm{ZnSO}_{4} \cdot 7 \mathrm{H}_{2} \mathrm{O}$, $11.5 \mu \mathrm{M} \mathrm{H}_{3} \mathrm{BO}_{3}, 3.5 \mu \mathrm{M} \mathrm{MnCl}_{2} \cdot 4 \mathrm{H}_{2} \mathrm{O}, 0.1 \mu \mathrm{M}\left(\mathrm{NH}_{4}\right) 6 \mathrm{Mo}_{7} \mathrm{O}_{24} \cdot 4 \mathrm{H}_{2} \mathrm{O}$, $25 \mu \mathrm{M} \mathrm{FeSO} \cdot 7 \mathrm{H}_{2} \mathrm{O}$, and $25 \mu \mathrm{M}$ ethylenediaminetetraacetic acid disodium. The $\mathrm{Si}$, which was provided as monosilicic acid, was obtained by passing potassium silicate (PQ Corporation, São Paulo, Brazil) through a cation exchange resin (Amberlite IR-120B, $\mathrm{H}^{+}$form, Sigma-Aldrich, São Paulo, Brazil) (Ma et al. 2002). The Si concentrations used were $0(-\mathrm{Si})$ and $2 \mathrm{mM}(+\mathrm{Si})$. The addition of monosilicic acid to the nutrient solution did not alter the $\mathrm{pH}$.

Rice seeds from the Primavera cultivar, which is susceptible to leaf scald, were surface-sterilized in $10 \%$ (vol/vol) $\mathrm{NaOCl}$ for $2 \mathrm{~min}$, rinsed in sterilized water for $3 \mathrm{~min}$, and germinated on distilled water-soaked germitest paper in a germination chamber (MA-835/2106UR; Marconi, São Paulo, Brazil) at $25^{\circ} \mathrm{C}$ for 6 days. The germinated seedlings were transferred to 5-liter plastic pots (30 cm diameter) (Ecovaso, Jaguariúna, SP, Brazil) with one-half strength nutrient solution without $\mathrm{Si}$ for 2 days. After this period, the plants were transferred to new plastic pots containing nutrient solution that was prepared with or without $\mathrm{Si}$. The nutrient solution, without aeration, was changed every 4 days. The $\mathrm{pH}$ was checked daily and maintained at approximately 5.5 using $\mathrm{NaOH}$ or $\mathrm{HCl}$ (1 M) when needed.

Plant inoculation with $M$. oryzae. The isolate of $M$. oryzae (UFV/DFP $M o$-022) used for plant inoculation was obtained from the leaves of rice plants of cultivar Bonança with typical symptoms of leaf scald. The isolate was preserved in glass vials containing potato dextrose agar (PDA), covered with mineral oil, and maintained at $4^{\circ} \mathrm{C}$. Plugs of PDA containing fungal mycelia were transferred to Petri dishes containing PDA. After 3 days, the PDA plugs containing the fungal mycelia were transferred to new Petri dishes that also contained PDA. The Petri dishes were maintained in a growth chamber (MA-835/2106UR; Marconi) at $25^{\circ} \mathrm{C}$ with a 12-h photoperiod for 15 days. Plants from each treatment were inoculated with $M$. oryzae after growing for 45 days (the emergence of the tenth leaf from the main tiller) (Matsuo and Hoshikama 1993) in a hydroponic culture containing 0 or $2 \mathrm{mM} \mathrm{Si}$. Three PDA discs $\left(0.3 \mathrm{~cm}^{2}\right)$ containing $M$. oryzae mycelia were equidistantly placed on the adaxial side of the seventh, eighth, and ninth leaves from the base to the apex of each plant and gently pressed onto the surface using the index finger. Immediately after inoculation, the plants were transferred to a plastic mist growth chamber (MGC) inside a greenhouse for the duration of the experiment. The MGC was constructed of wood ( $2 \mathrm{~m}$ wide, $1.5 \mathrm{~m}$ high, and $5 \mathrm{~m}$ long, covered with $100-\mu \mathrm{m}$ thick transparent plastic). The temperature inside the MGC ranged from $25 \pm 4^{\circ} \mathrm{C}$ (day) to $21 \pm 2{ }^{\circ} \mathrm{C}$ (night). The relative humidity was maintained at $92 \pm 3 \%$ using a misting system (model NEB-100; KGF Company, São Paulo, Brazil), which sprayed mist every $60 \mathrm{~min}$ above the plant canopies. The relative humidity and temperature were measured using a thermo-hygrograph (TH-508, Impac, São Paulo, Brazil). The maximum natural photon flux density at the height of the plant canopy was approximately $950 \mu \mathrm{mol} \mathrm{m} \mathrm{m}^{-2} \mathrm{~s}^{-1}$. The noninoculated plants were maintained in a separate MGC but were exposed to the same conditions as the inoculated plants.

Assessment of leaf scald development. The expansion (in millimeters) of the three lesions on the adaxial surface of the seventh, eighth, and ninth leaves from the base to the apex of each plant of each replicate of each treatment was measured using an electronic digital caliper (Neiko 01407A; Stainless Steel, Mandaluyong, Philippines) at 24, 36, 48, 72, 96, 120, and $144 \mathrm{~h}$ after inoculation (hai). The lesion expansion data were used to calculate the area under the leaf scald progress curve (AULSPC) according to Shaner and Finney (1980).

Processing the infected leaf fragments for the microscopic observations. Approximately 25 to 30 leaf fragments $\left(\approx 25 \mathrm{~mm}^{2}\right)$ from each inoculated plant of each replicate of each treatment were sampled from $3 \mathrm{~cm}$ below and above the inoculation point at 24, 36, 48, 72, 96, 120, and 144 hai. The leaf fragments were carefully transferred to glass vials containing $10 \mathrm{ml}$ of a fixative composed of $3 \%$ ( vol/vol) glutaraldehyde and $2 \%$ paraformaldehyde ( $\mathrm{vol} / \mathrm{vol})$ in $0.1 \mathrm{M}$ sodium cacodylate buffer ( $\mathrm{pH} 7.2)$. The vials were stored at $4^{\circ} \mathrm{C}$ for 2 months until they were used for the microscopy observations.

$\mathbf{X}$-ray microanalysis. The insoluble elemental composition and relative levels of the leaf fragments from the $-\mathrm{Si}$ and + Si plants collected at 36 and 72 hai were investigated by energy dispersive $\mathrm{X}$-ray spectroscopy (EDS) using a scanning electron microscope (LEO 1430VP, Carl Zeiss, Jena, Thuringia, Germany) with an attached X-ray detector system (Tracor TN5502, Middleton, WI) (Araujo et al. 2014b). The samples were dehydrated in ethanol and
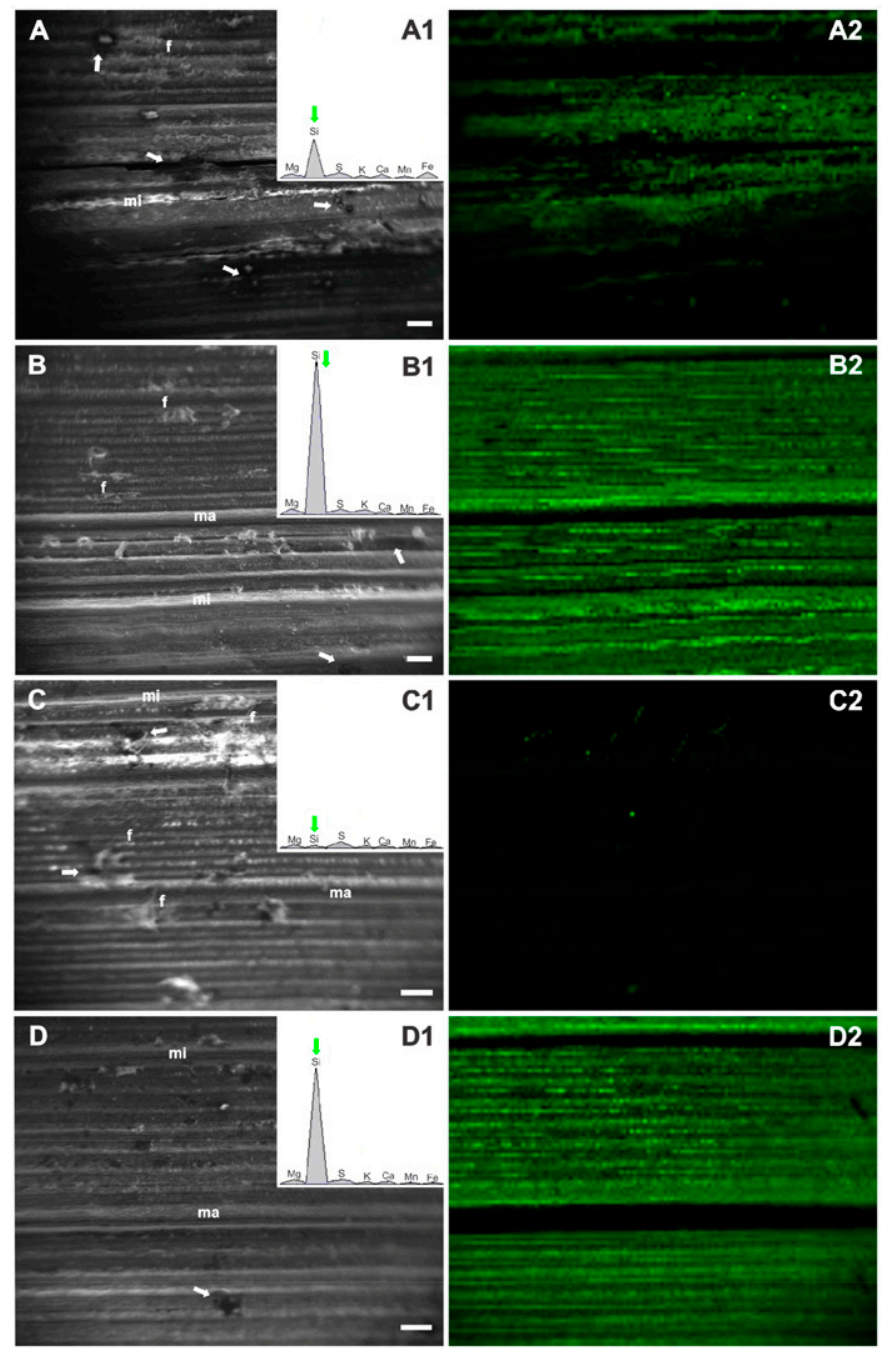

Fig. 1. Scanning electron micrographs (A, B, C, and D), X-ray emission spectra (A1, B1, C1, and D1), and corresponding X-ray maps for silicon (Si) $(\mathrm{A} 2, \mathrm{~B} 2, \mathrm{C} 2$, and D2) on the adaxial leaf surface of rice plants grown in a hydroponic culture containing $0(-\mathrm{Si})(\mathrm{A}$ and $\mathrm{C})$ or $2 \mathrm{mM}(+\mathrm{Si})$ silicon $(\mathrm{Si})(\mathrm{B}$ and D) at 36 (A and B) and 72 (C and D) hours after inoculation with Microdochium oryzae. A and C, Fungal hyphae extensively colonized the adaxial leaf surface of the $-\mathrm{Si}$ plants causing intense tissue degradation (arrows), especially at the major and minor veins. B and D, Fungal hyphae were also observed on the adaxial leaf surface of the $+\mathrm{Si}$ plants without causing extensive tissue degradation (arrows). The Si peaks for the adaxial leaf surface of the $-\mathrm{Si}$ (A1 and $\mathrm{C} 1$ ) and + Si (B1 and D1) plants were higher compared with the other six chemical elements but were considerably higher for the $+\mathrm{Si}$ plants. In the X-ray maps, green fluorescent dots correspond to Si deposition on the adaxial leaf surface of the $-\mathrm{Si}$ (A2 and $\mathrm{C} 2$ ) and $+\mathrm{Si}$ (B2 and D2) plants. Black indicates the absence of Si. Fungal hyphae (f), major vein (ma), and minor vein $(\mathrm{mi})$. Scale bars $=200 \mu \mathrm{m}$. 
submitted to critical point drying in $\mathrm{CO}_{2}$ (Bal-tec, model CPD 030; Electron Microscopy Sciences (EMS), Hatfield, PA). The specimens were mounted onto aluminum stubs (two specimens from each leaf fragment) and coated with a thin film of evaporated carbon (Quorum Q150 T, East Grinstead, West Sussex, England, UK).

Because soluble (diffusible) elements are lost during liquid ethanol dehydration and substitution with liquid $\mathrm{CO}_{2}$, the remaining elements should be considered largely bound to cell components and therefore insoluble (Zeyen et al. 1993). The EDS microanalysis on all leaf fragments examined was performed at magnifications of $40 \times$ with an accelerating voltage of $20 \mathrm{kV}$ and a working distance of $19 \mathrm{~mm}$. For each treatment, a total area of $18 \times 10^{7} \mu \mathrm{m}^{2}$ was analyzed for each leaf fragment. The distribution patterns of calcium $(\mathrm{Ca})$, iron $(\mathrm{Fe})$, magnesium $(\mathrm{Mg})$, manganese $(\mathrm{Mn})$, potassium $(\mathrm{K}), \mathrm{Si}$, and sulfur $(\mathrm{S})$ were based on secondary electron images, X-ray emission spectra and corresponding X-ray elemental maps according to the methods of Araujo et al. (2014b). A total of 10 images were obtained from the leaf fragments of each treatment.

Scanning electron microscopy. Leaf fragments from the $-\mathrm{Si}$ and + Si plants collected at 36 and 72 hai were washed with sodium cacodylate buffer $(0.1 \mathrm{M})$ and postfixed with $1 \%$ (wt/vol) osmium tetroxide prepared in the same buffer for $1 \mathrm{~h}$ at room temperature (Araujo et al. 2014b). The samples were dehydrated, mounted on aluminum stubs, and sputter coated with gold (Balzers Union, model FDU 010; EMS). The electron photomicrographs were obtained using an LEO scanning electron microscope (SEM) operating at $10 \mathrm{Kv}$, with a working distance ranging from 10 to $30 \mathrm{~mm}$. For each treatment, two stubs with two leaf fragments were examined using SEM.

Processing the infected leaf fragments for light microscopy. Leaf fragments from the $-\mathrm{Si}$ and $+\mathrm{Si}$ plants collected at 36 and 72 hai were washed with $0.1 \mathrm{M}$ sodium cacodylate buffer, subsequently dehydrated through a graded alcohol series $(10,30,50,70,85,95$, and 100\%) and then embedded in methacrylate resin (Historesin, Leica Microsystems, Nussloch/Heidelberg, Germany) (Araujo et al. 2014a, 2015). During the preinfiltration and infiltration steps, the leaf fragments were placed in a vacuum chamber for $2 \mathrm{~h}$ both in the morning and in the afternoon for three weeks to allow better resin infiltration into the leaf tissue. The samples were stored at $4{ }^{\circ} \mathrm{C}$ after each vacuum procedure. In total, six blocks of resin, each containing two leaf fragments, were obtained for each treatment at each sampling time. A total of 36 longitudinal, tangential, and transverse serial sections ( $4 \mu \mathrm{m}$ thick), which were cut from each block using a Leica RM 2245 rotary microtome (Leica Microsystems), were randomly divided and placed on three glass slides and stained with $1 \%$ toluidine blue in $2 \%$ sodium borate for $5 \mathrm{~min}$. Toluidine blue is a metachromatic dye commonly used for staining plant tissue sections (Vermerris and Nicholson 2006). Typical host defense mechanisms such as the accumulation of phenolics to prevent further fungal colonization was obtained by staining sections of mango stem and rice leaves with toluidine blue (Araujo et al. 2014a, 2015; Rodrigues et al. 2004). When the specimen samples stained with toluidine blue are viewed under the light microscope, distinct different cell components produce different colors: DNA is bluish green; RNA is violet; the middle lamella is red; nonlignified cell walls and soluble phenolics are red-violet, blue-violet, blue, or purple; and polymerized phenolics such as lignin become green or bluish green (Vermerris and Nicholson 2006). The images of the details regarding fungal infection and host defense responses were acquired digitally (Axio Cam HR, Carl Zeiss) using a Carl Zeiss Axio Imager A1 microscope in the bright-field mode and further processed using AXION VISION v. 4.8.1 software.

Transmission electron microscopy. Leaf fragments from the $-\mathrm{Si}$ and $+\mathrm{Si}$ plants collected at 36 and 72 hai were washed and postfixed with $1 \%$ (wt/vol) osmium tetroxide for $1 \mathrm{~h}$ at room temperature. The samples were then dehydrated and embedded in Spurr's resin (EMS, Hatfield, PA) at gradients of 25 and $33 \%$ for $1 \mathrm{~h}$, gradients of 50,66, and $75 \%$ for $12 \mathrm{~h}$, and then $100 \%$ resin for $36 \mathrm{~h}$ (Araujo et al. 2014b). The samples were placed in a vacuum chamber for $3 \mathrm{~min}$ at each gradient to allow better resin infiltration. The samples were mounted in flat embedding molds, embedded in pure Spurr's resin and polymerized in an oven at $65^{\circ} \mathrm{C}$ for $24 \mathrm{~h}$. Thick sections $(0.5 \mu \mathrm{m})$ were cut from the embedded material with glass knives using a Leica RM 2245 rotary microtome (Leica Microsystems). The sections were stained with $1 \%$ toluidine blue in $2 \%$ sodium borate for $5 \mathrm{~min}$ for light microscope observations. Once the infection threads were located under the light microscope, ultrathin sections $(70 \mathrm{~nm})$ were collected from the embedded material using the diamond knife (Diatome, Hatfield, PA) of a Power Tome-X ultramicrotome (RMC, Boeckeler Instruments, Tucson, AZ). The ultrathin sections were mounted on copper grids (200-mesh square), stained with $2 \%$ uranyl acetate and $1 \%$ lead acetate for 20 and $10 \mathrm{~min}$, respectively, and then examined using a transmission electron microscope (Zeiss EM 109, Carl-Zeiss) operating at $80 \mathrm{Kv}$. For each treatment, four blocks were carefully selected for cuttings, and from each block, 10 thick and eight to sixteen ultrathin sections were examined under the light and transmission electron microscopes, respectively.

Determination of leaf Si concentration. After the completion of the experiments, the leaves that were used to evaluate the expansion of the leaf scald lesions were collected, washed with deionized water, and dried at $65^{\circ} \mathrm{C}$ for $72 \mathrm{~h}$. Next, the leaves were ground in a Thomas-Wiley mill with a 40-mesh sieve. The foliar $\mathrm{Si}$ concentration was determined via a colorimetric analysis of the alkaline digestion of $0.1 \mathrm{~g}$ of dry leaf tissue (Korndörfer et al. 2004).

Experimental design and statistical analysis. An experiment consisting of two treatments ( $-\mathrm{Si}$ and $+\mathrm{Si}$ plants) was arranged in a completely randomized design with five replications. Each
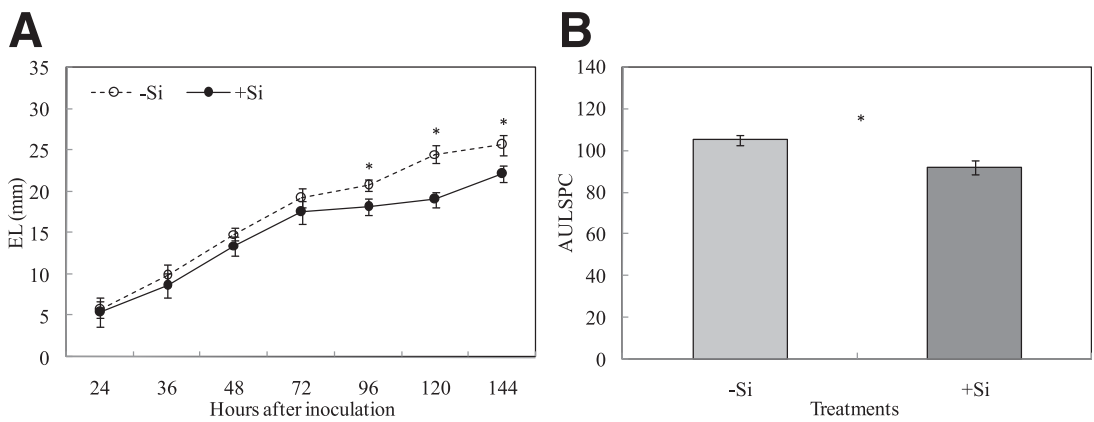

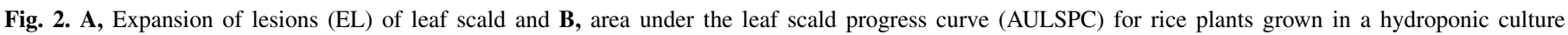

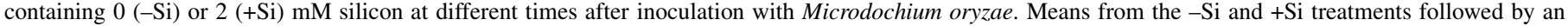
asterisk $(*)$ are significantly different $(P \leq 0.05)$ based on the $t$ test. Error bars represent the standard deviation of the means $(n=5)$ 
replication corresponded to a plastic pot with five plants. The experiment was repeated once. The data were submitted to analysis of variance, and the treatment means were compared with the $t$ test $(P \leq 0.05)$ using SAS software (Release 8.02 Level 02M0 for Windows; SAS Institute, Inc., Cary, NC).

\section{RESULTS}

Foliar Si concentration. The foliar $\mathrm{Si}$ concentration of the $+\mathrm{Si}$ plants was significantly higher $(3.6 \mathrm{dag} / \mathrm{kg})$ than their $-\mathrm{Si}$ counterparts $(0.3 \mathrm{dag} / \mathrm{kg})$ (data not shown).

X-ray microanalysis. Fungal hyphae extensively colonized the adaxial leaf surface of $-\mathrm{Si}$ plants and caused intense tissue degradation at 36 and 72 hai (Fig. 1A and C). Fungal hyphae were also observed on the adaxial leaf surface of + Si plants at 36 and 72 hai but did not cause considerable tissue degradation (Fig. 1B and D). At 36 and 72 hai, the peaks of insoluble Si on the leaf surface of $+\mathrm{Si}$ plants were $\approx 304$ and $10,000 \%$ higher, respectively, compared with the $-\mathrm{Si}$ plants (Fig. 1A1 to D1). Higher levels of Si deposition were noticed on the adaxial leaf surface of $+\mathrm{Si}$ plants colonized by $M$. oryzae compared with the $-\mathrm{Si}$ plants regardless of the evaluation time (Fig. 1A2 to D2).

Lesion expansion and the AULSPC. The expansion of the leaf scald lesions on the leaves of the $+\mathrm{Si}$ plants was significantly reduced by 13,22 , and $14 \%$ at 96,120 , and 144 hai, respectively, compared with the -Si plants (Fig. 2A). The AULSPC significantly
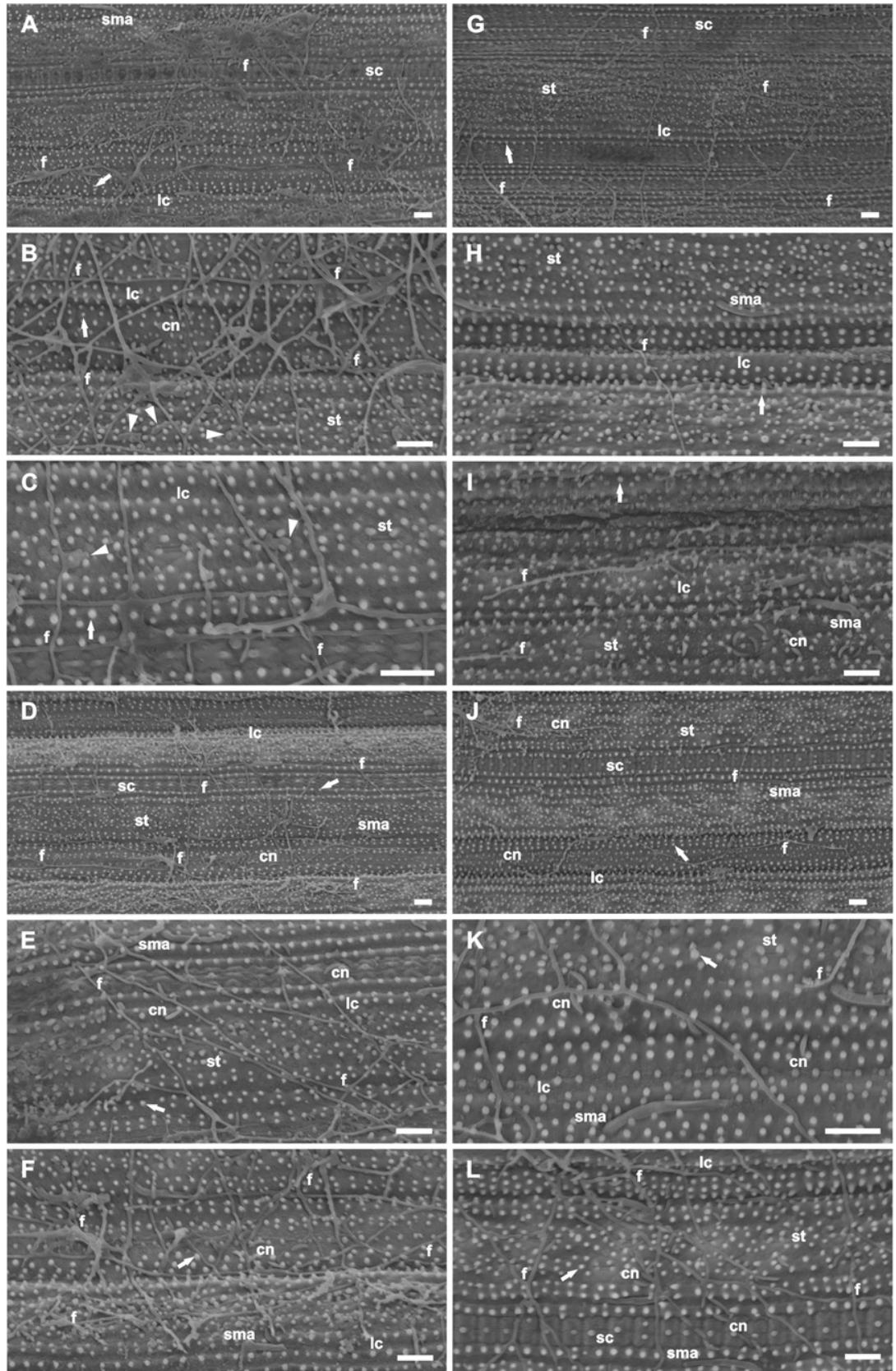

Fig. 3. Scanning electron micrographs of the adaxial leaf surface of rice plants grown in a hydroponic culture containing $0(-\mathrm{Si})(\mathrm{A}$ to $\mathrm{F})$ or $2 \mathrm{mM}(+\mathrm{Si})$ silicon $(\mathrm{G}$ to $\mathrm{L}$ ) at 36 (A to $\mathrm{C}$ and $\mathrm{G}$ to I) and 72 (D to F and J to L) hours after inoculation with Microdochium oryzae. A to F, Hyphae of M. oryzae grew abundantly over and between the long and short cells, papillae (arrows), special types of macro hairs and stomata. Many nongerminated conidia next to the fungal hyphae were observed on the adaxial leaf surface. B and C, Some fungal hyphae passed over the stomata without any sign of penetration, and some formed appressorium-like structures (arrowheads) over the stomata. D to F, Many special types of macro hairs appeared to be degraded at the infection site. G to L, Fungal hyphae and nongerminated conidia were rarely observed on the adaxial leaf surface of the +Si plants. Conidia (cn), fungal hyphae (f), long cells (lc), short cells (sc), special types of macro hairs (sma), and stomata (st). Scale bars $=20 \mu \mathrm{m}$. 
decreased by $12 \%$ for the leaves of the +Si plants compared with the $-\mathrm{Si}$ ones (Fig. 2B).

SEM. Hyphae of M. oryzae grew abundantly over and between long and short cells, papillae, special types of macro hairs, and stomata on the adaxial leaf surface of the -Si plants at 36 and 72 hai (Fig. 3A to F). By contrast, for the + Si plants, fungal hyphae were rarely observed on the adaxial leaf surface (Fig. $3 \mathrm{G}$ to $\mathrm{L}$ ). Nongerminated conidia were observed next to the fungal hyphae on the adaxial leaf surface of both the -Si and +Si plants at 36 and 72 hai (Fig. 3). On the adaxial leaf surface of the $-\mathrm{Si}$ plants, some fungal hyphae passed over stomata without any sign of penetration and some of them formed appressorium-like structures over the stomata at 36 hai (Fig. 3B and C). The formation of the appressorium-like structures of $M$. oryzae on the adaxial leaf surface of the +Si plants was not noticed (Fig. 3G to I). At 72 hai, many special types of macro hairs seemed to be degraded by M. oryzae on the adaxial leaf surface of the-Si plants (Fig. 3D to F). By contrast, the special types of macro hairs on the adaxial leaf surface of the + Si plants rarely seemed to be degraded (Fig. $3 \mathrm{~J}$ to L).

Light microscopy. The hyphae of $M$. oryzae apparently grew without any impedance in the bulliform and mesophyll cells, intercellular spaces, and vascular bundles in the leaf tissue of the $-\mathrm{Si}$ plants at 36 and 72 hai (Fig. 4A to J). In contrast, in the leaf tissue of the $+\mathrm{Si}$ plants, most of the cells that were colonized by fungal
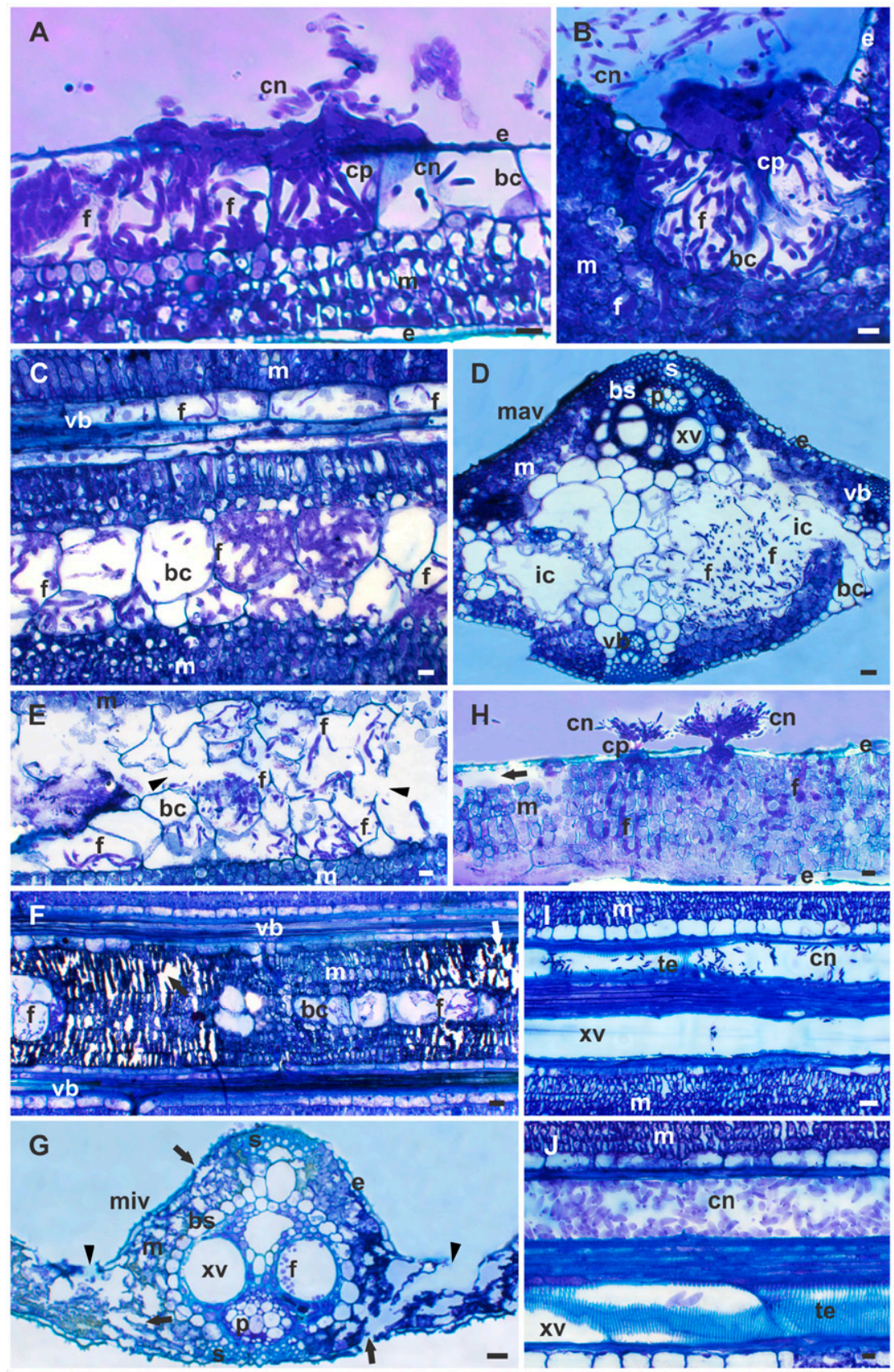

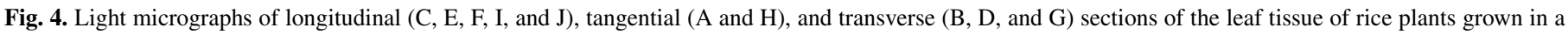

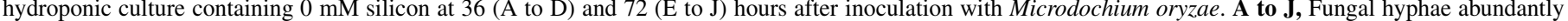

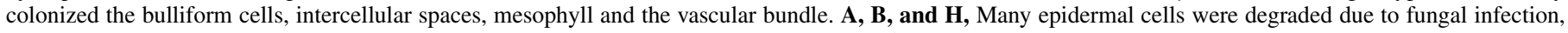

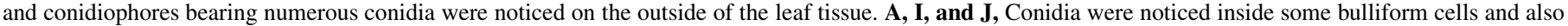

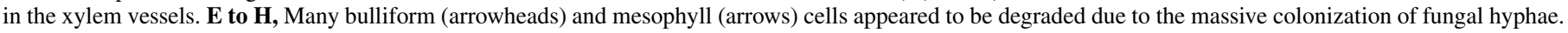

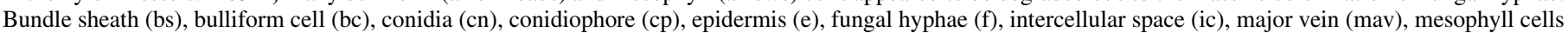

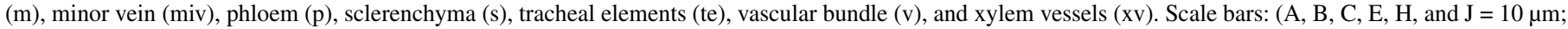
and $\mathrm{D}, \mathrm{F}, \mathrm{G}$, and $\mathrm{I}=20 \mu \mathrm{m})$. 
hyphae reacted strongly to fungal invasion through the deposition of phenolic-like compounds (Fig. 5A to K). In these cells, the fungal hyphae frequently appeared to be dead (empty) and were encrusted with phenolic-like compounds (Fig. 5A to K). At 36 and 72 hai, the fungal hyphae seemed to degrade the epidermis, and conidiophores bearing numerous conidia appeared on the outside of the leaf tissue of the -Si plants (Fig. 4A, B, and H). The same M. oryzae structures were not observed in the leaf tissue of the +Si plants (Fig. 5A to K). In the $-\mathrm{Si}$ plants, conidia were also noticed inside some of the bulliform cells and xylem vessels (Fig. 4A, I, and J). In contrast, conidia were rarely noticed inside these cells in the leaf tissue of the + Si plants (Fig. 5D).
Transmission electron microscope. Fungal hyphae fully colonized the mesophyll cells of the leaf tissue of the -Si plants (Fig. 6). In the leaf tissue of the + Si plants, the fungal hyphae and conidia in the mesophyll cells were often surrounded by dense amorphous granular material (Fig. 7B, D, E, and F). The cell walls of the mesophyll cells in the leaf tissue of the -Si plants showed signs of intense degradation due to the extensive colonization by $M$. oryzae hyphae (Fig. 6A to C). By contrast, the epidermis and mesophyll cell walls of the leaf tissue of the +Si plants were rarely degraded by fungal hyphae, and these cells were encrusted by an amorphous granular material (Fig. 7A to C). Long and thick fungal hyphae were often found in leaf tissue of the-Si plants (Fig. 6C to F), whereas the fungal
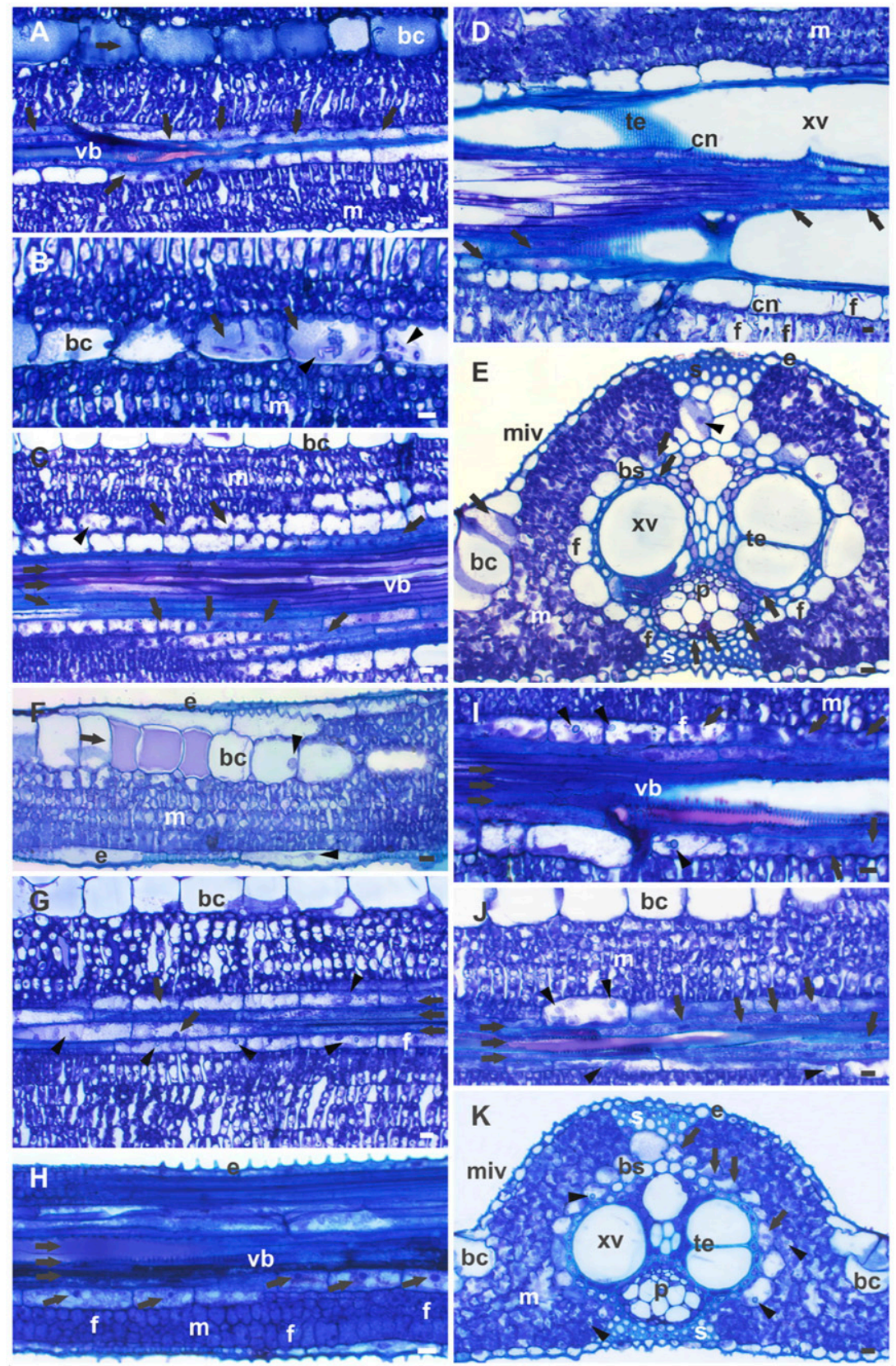

Fig. 5. Light micrographs of longitudinal (A, B, C, D, G, I, and J), tangential (F and H), and transverse (E and K) sections of the leaf tissue of rice plants grown in a hydroponic culture containing $2 \mathrm{mM}$ silicon at 36 (A to E) and 72 (F to K) hours after inoculation with Microdochium oryzae. A to K, Fungal hyphae occasionally colonized the bundle sheath, bulliform and mesophyll cells as well as the vascular bundle. These host cells reacted strongly against fungal invasion by staining dark-blue or purple (arrows), which indicated the presence of phenolic-like compounds, whereas others accumulated amorphous granular material around the fungal hyphae (arrows). Many fungal hyphae appeared dead (arrowheads). D, Conidia were rarely observed inside the bulliform cells and the xylem vessels. K, The bulliform cells occasionally showed signs of deformation due to fungal colonization. Bundle sheath (bs), bulliform cell (bc), conidia (cn), conidiophores (cp), epidermis (e), fungal hyphae (f), major vein (mav), mesophyll cells (m), minor vein (miv), phloem (p), sclerenchyma (s), tracheal elements (te), vascular bundle (v), and xylem vessels (xv). Scale bars: $10 \mu \mathrm{m}$. 
hyphae in the leaf tissue of the + Si plants were thin and faint (Fig. 7B, D, and E) and sometimes appeared to be dead (Fig. 7C and F).

\section{DISCUSSION}

The present study provides, to the best of the authors' knowledge, the first microscopic evidence that the deposition of phenolic-like compounds is closely associated with a reduction in $M$. oryzae colonization of the leaf tissue of rice plants amended with $\mathrm{Si}$. The peaks and deposition of bound and/or insoluble Si in the leaf tissue of the $+\mathrm{Si}$ plants infected by $M$. oryzae were always higher than those obtained from the leaf tissue of the-Si plants, which therefore explains the increase in rice resistance to leaf scald. It is known that a high foliar Si concentration increases the resistance of several plant species, especially grasses, to many foliar pathogens (Datnoff et al. 2007). Kim et al. (2002) used X-ray microanalysis and showed that $\mathrm{Si}$ deposition was prevalent throughout the leaf tissue of $+\mathrm{Si}$ plants, which reduced the number of blast lesions. Domiciano et al. (2010) also used X-ray microanalysis and reported high levels of Si deposition in the epidermal cells of wheat plants supplied with $\mathrm{Si}$ that were more resistant to spot blotch.

Both the leaf scald lesion expansion and AULSPC were reduced in the $+\mathrm{Si}$ plants. The beneficial effects of $\mathrm{Si}$ with respect to decreasing the intensity of several diseases of rice (Datnoff et al. 2007), including leaf scald (Tatagiba et al. 2014), are already well known. The effect of $\mathrm{Si}$ is frequently associated with a prevention or delay in the pathogen penetration (Hayasaka et al. 2008; Kim et al. 2002; Yoshida et al. 1962), an increase in the production of phenolic compounds (Bélanger et al. 2003; Fortunato et al. 2014; Rodrigues et al. 2003, 2005; Tatagiba et al. 2014), increases in the levels of some classes of phytoalexins (Rodrigues et al. 2004) and strong activation of some pathogenesis-related proteins-genes (Rodrigues
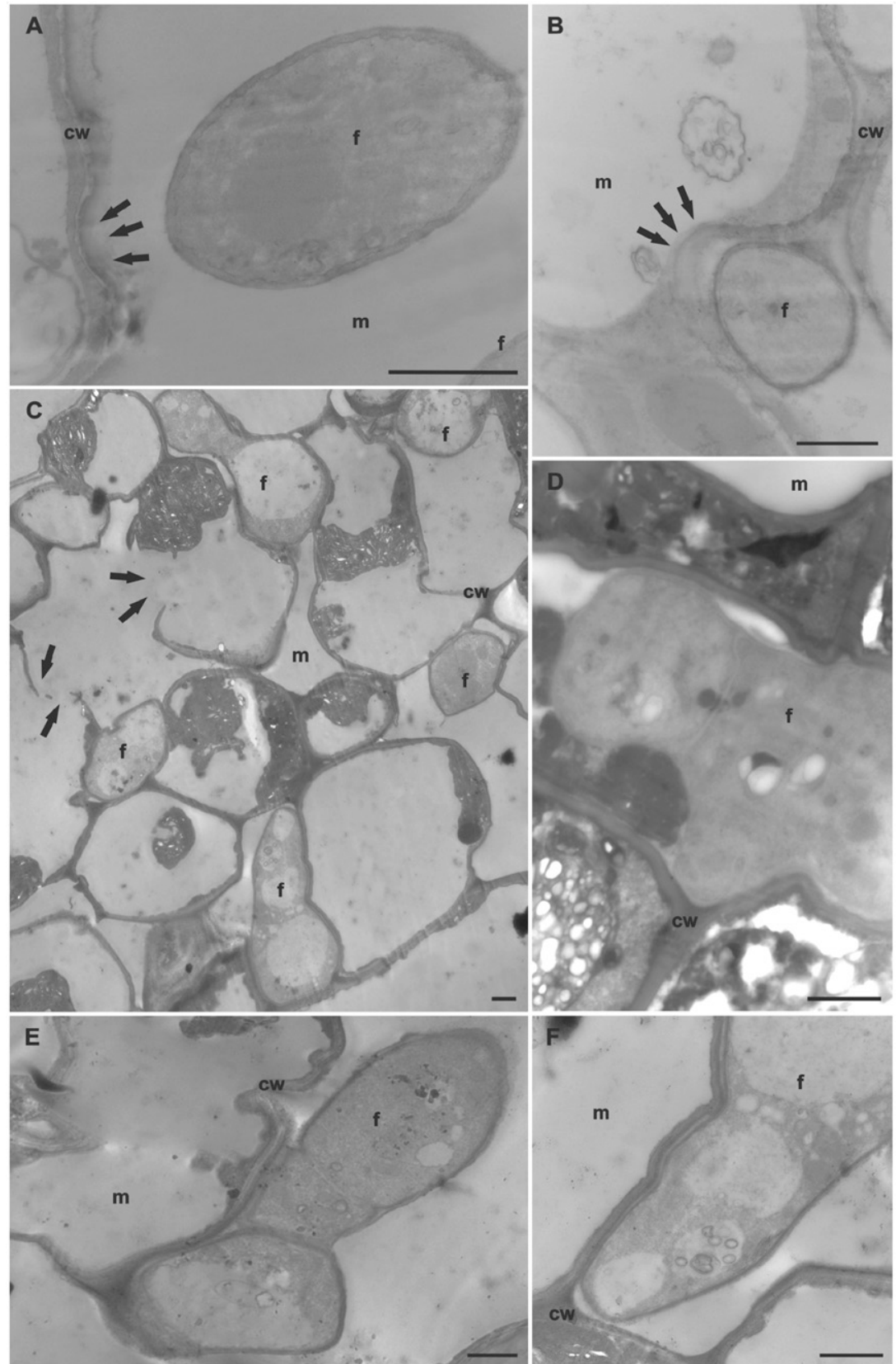

Fig. 6. Transmission electron micrographs of longitudinal (C, D, E, and F) and transverse (A and B) sections of the leaf tissue of rice plants grown in a hydroponic culture containing $0 \mathrm{mM}$ silicon at 36 (A to B) and 72 (C to F) hours after inoculation (hai) with Microdochium oryzae. A and B, At 36 hai, fungal hyphae colonized the mesophyll cells and the host cell walls showed signs of deformation (arrows). C to F, At 72 hai, long and thick fungal hyphae broadly invaded the mesophyll cells and caused intense degradation of the host cell walls (arrows). Host cell wall (cw), fungal hyphae (f), and mesophyll cells $(\mathrm{m})$. Scale bars $=1 \mu \mathrm{m}$. 
et al. 2005). In the present study, it is plausible that the decrease in the leaf scald severity in the + Si plants may be due to the higher foliar Si concentration that negatively impaired $M$. oryzae colonization.

Based on the SEM observations, fungal hyphae were more abundant on the leaf surface of $-\mathrm{Si}$ plants in contrast to the $+\mathrm{Si}$ plants. Furthermore, on the leaf surface of the -Si plants, some fungal hyphae formed appressorium-like structures over the stomata while such an event was rarely noticed for the + Si plants. Hayasaka et al. (2008) used SEM and X-ray microanalysis and showed that the frequency of appressorial penetration of $P$. oryzae in the leaf blades of rice plants supplied with $\mathrm{Si}$ was reduced, resulting in lower blast severity. Kim et al. (2002) reported that high $\mathrm{Si}$ deposition in the leaf tissue of rice plants reduced
P. oryzae penetration and its further colonization by acting as a physical barrier. In the present study, the high Si concentration and deposition in the leaves of the $+\mathrm{Si}$ plants may have affected the appressoria-like formation of $M$. oryzae or acted as a physical barrier that hampered fungal penetration and leaf tissue colonization.

At both the histopathological and ultrastructural levels, fungal hyphae apparently grew without any impedance in the cells of the leaf tissue of the $-\mathrm{Si}$ plants. In contrast, in the leaf tissue of the $+\mathrm{Si}$ plants, most cells reacted to $M$. oryzae infection by accumulating phenolic-like compounds or amorphous granular material, which possibly contributed to the dead appearance of many fungal hyphae. The presence of amorphous material, which is frequently reported
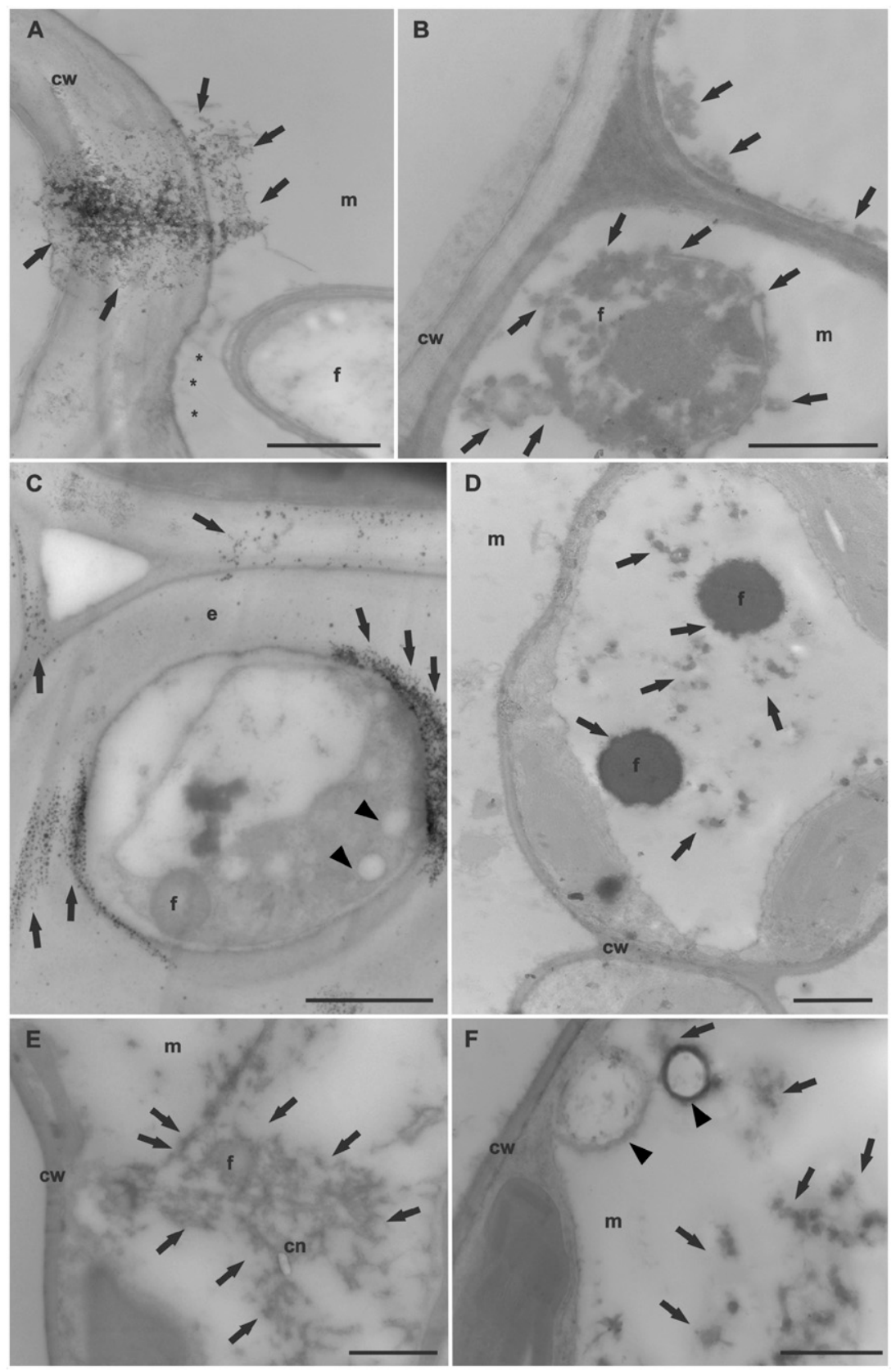

Fig. 7. Transmission electron micrographs of longitudinal (D and F), tangential (E), and transverse (A, B, and C) sections of the leaf tissue of rice plants grown in a hydroponic culture containing $2 \mathrm{mM}$ silicon at 36 (A to B) and 72 (C to F) hours after inoculation with Microdochium oryzae. A, Fungal hyphae colonized the mesophyll cells, and the host cell walls showed signs of deformation (asterisks). The colonized host cells reacted against fungal infection with an intense deposition of amorphous granular material (arrows). B and C, Amorphous granular material (arrows) accumulated in the epidermis and mesophyll cells and regularly interacted with fungal hyphae as well as with the host cell wall. D to F, Fungal hyphae and conidia found in the mesophyll cells were frequently trapped by an amorphous granular material (arrow). C and F, Some fungal hyphae appeared dead (arrowheads) due to the presence of amorphous granular material. Conidia (cn), epidermis (e), host cell wall (cw), fungal hyphae (f), and mesophyll cells (m). Scale bars $=1 \mu \mathrm{m}$. 
to be of phenolic nature, is a typical feature of cellular defense used by many plant species to cope with fungal infection (Araujo et al. 2014a, b, 2015; Bélanger et al. 2003; Rodrigues et al. 2003). Rodrigues et al. (2003) reported the occurrence of empty $P$. oryzae hyphae surrounded by amorphous material in the cells of $+\mathrm{Si}$ rice plants. Bélanger et al. (2003) used histopathological and ultrastructural analyses and observed that the epidermal cells of wheat plants supplied with Si reacted to $B$. graminis $\mathrm{f}$. sp. tritici infection with specific defense mechanisms including papilla formation, the production of callose and the release of phenolic-like compounds. Phenolic material not only accumulated along the cell wall, but was also associated with altered haustorial integrity produced by the fungus (Bélanger et al. 2003). The fungitoxic effects of most phenolics are attributed to their interactions with lipids or phospholipids, which increase fungal membrane permeability, leakage of hyphal contents and cytoplasm aggregation (Weete 1980). Tatagiba et al. (2014) reported that high concentrations of total soluble phenolics and ligninthioglycolic acid derivatives in association with greater activities of peroxidases, polyphenoloxidases, phenylalanine ammonialyases, and lipoxygenases in the leaves of $+\mathrm{Si}$ plants contributed to a reduction in the severity of leaf scald. These findings of Tatagiba et al. (2014) are consistent with the data obtained at the microscopic level in the present study, which clearly indicate the importance of $\mathrm{Si}$ in the potentiation of phenolic-like compound production to increase rice resistance against $M$. oryzae infection.

The fungal hyphae appeared to degrade the epidermis, and conidiophores bearing numerous conidia were observed on the outside of the leaf tissue of the-Si plants at 36 hai. Conidiophores of M. oryzae grow out from the stomata and produce conidia from $72 \mathrm{~h}$ after fungal penetration (Bedendo and Prabhu 2005; Filippi and Prabhu 2005). The results from the present study clearly show that the conidiophores of $M$. oryzae emerged from the stomata and were able to disrupt the epidermis with the production of conidia starting at 36 hai in the leaves of the -Si plants. However, conidiophores of $M$. oryzae were rarely noticed in the leaf tissue of the $+\mathrm{Si}$ plants, most likely due to the high $\mathrm{Si}$ concentration and deposition that probably acted as a physical barrier against fungal sporulation.

Numerous conidia of $M$. oryzae were noticed inside some bulliform and mesophyll cells and xylem vessels in the leaf tissue of the-Si plants. In contrast, conidia were rarely noticed in these cells in the leaf tissue of the +Si plants. According to Elarosi (1956), conidia of true fungi are rarely reported to form inside plant cells. In the few cases reported, the conidia were frequently observed inside of the vessels, e.g., the microconidia produced by Fusarium oxysporum f. sp. cubense in the xylem cells of banana roots (Elarosi 1956). Araujo et al. (2014a, b, 2015) observed many aleurioconidia of Ceratocystis fimbriata in the xylem vessels, medullary radius, and parenchyma cells of the stem tissues of mango plants. The present study is the first to report, to the best of the authors' knowledge, the presence of $M$. oryzae conidia inside rice leaf cells, specifically in the xylem vessels. Although the function of these conidia is unknown in rice $-M$. oryzae, it is important to notice that their formation was greatly affected in the + Si plants and may contribute negatively to the leaf scald epidemic considering that the survival of the fungus in the crop residues will be negatively impacted.

The leaf tissue of the -Si plants that was massively colonized by the fungal hyphae of $M$. oryzae showed strong signs of degradation. In contrast, the leaf tissue of the $+\mathrm{Si}$ plants was rarely degraded or was encrusted by the deposition of an amorphous granular material. The $M$. oryzae is a necrotrophic pathogen that destroys leaf cells due to the intense production of hydrolytic enzymes and nonhost specific toxins to obtain the necessary nutrients for massive growth (Ou 1985). According to Rodrigues et al. (2003), the mesophyll cells of rice plants supplied with $\mathrm{Si}$ were less colonized by $P$. oryzae hyphae and showed less disorganization and cell wall alterations in comparison with the -Si plants. Fortunato et al. (2014) reported that the phenylpropanoid pathway was potentiated by $\mathrm{Si}$ in the roots of banana plants infected by $F$. oxysporum f. sp. cubense. These authors postulated that lignin, lignin polymers and other phenolics deposited in the roots of plants supplied with Si were important mechanisms against fungal infection due to their effect on the strength of the host cell walls in addition to their effect in preventing or reducing the diffusion of lytic enzymes and nonhost selective toxins produced by the fungus (Fortunato et al. 2014). In the present study, the reduced damage in the leaf tissue of the $+\mathrm{Si}$ plants caused by $M$. oryzae infection was most likely due to the antimicrobial and protective effects of the phenolic-like compounds.

In conclusion, marked differences in the infection process of M. oryzae were noticed in the leaf tissue of the + Si plants in contrast to their $-\mathrm{Si}$ counterparts at the microscopic level. The high concentration and deposition of $\mathrm{Si}$ and the considerable accumulation of phenolic-like compounds in the leaf tissue of plants supplied with Si indicated that the potentiation of the phenylpropanoid pathway was favorable for the increase in rice resistance to leaf scald.

\section{ACKNOWLEDGMENTS}

F. A. Rodrigues thanks the Conselho Nacional de Desenvolvimento Científico e Tecnológico (CNPq) for his fellowship. L. Araujo thanks the CNPq for his postdoctoral fellowship (Process PDJ-502252/2013-8). We thank the "Núcleo de Microscopia e Microanálise" of Viçosa Federal University for the use of their equipment for this study. This study was supported by grants from CNPq and the Fundação de Amparo à Pesquisa do Estado de Minas Gerais (FAPEMIG) awarded to F. A. Rodrigues.

\section{LITERATURE CITED}

Araujo, L., Bispo, W. M. S., Cacique, I. S., Cruz, M. F. A., and Rodrigues, F. A. 2014a. Histopathological aspects of mango resistance to the infection process of Ceratocystis fimbriata. Plant Pathol. 63:1282-1295.

Araujo, L., Bispo, W. M. S., Cacique, I. S., Moreira, W. R., and Rodrigues, F. A. 2014b. Resistance in mango against infection by Ceratocystis fimbriata. Phytopathology 104:820-833.

Araujo, L., Bispo, W. M. S., Rios, V. S., Fernandes, S. A., and Rodrigues, F. A. 2015. Induction of the phenylpropanoid pathway by acibenzolar-s-methyl and potassium phosphite increases mango resistance to Ceratocystis fimbriata infection. Plant Dis. 99:447-459.

Araújo, L. G., Prabhu, A. S., and Silva, G. B. 2001. Resistência de somaclones da cultivar de arroz IAC 47 a Monographella albescens. Fitopatol. Bras. 26: 165-169.

Bedendo, I. P., and Prabhu, A. S. 2005. Doenças do arroz (Oryza sativa). Pages 79-90 in: Manual de Fitopatologia: Doenças das Plantas Cultivadas. H. Kimati, L. Amorim, A. Bergamin-Filho, L. E. A. Camargo, and J. A. M. Rezende, eds. Agronômica Ceres, São Paulo.

Bélanger, R. R., Benhamou, N., and Menzies, J. G. 2003. Cytological evidence of an active role of silicon in wheat resistance to powdery mildew (Blumeria graminis f. sp. tritici). Phytopathology 93:402-412.

Datnoff, L. E., Rodrigues, F. A., and Seebold, K. W. 2007. Silicon and plant disease. Pages 233-246 in: Mineral Nutrition and Plant Disease. L. E. Datnoff, W. H. Elmer, and D. M. Huber, eds. The American Phytopathological Society, St. Paul, MN.

Domiciano, G. P., Rodrigues, F. A., Vale, F. X. R., Xavier-Filha, M. S., Moreira, W. R., Andrade, C. C. L., and Pereira, S. C. 2010. Wheat resistance to spot blotch potentiated by silicon. J. Phytopathol. 158:334-343.

Elarosi, H. M. 1956. Sporulation of fungi inside the plant cell host. Nature 177:665-666.

Filippi, M. C. C., and Prabhu, A. S. 2005. Escaldadura do arroz e seu controle. Circular Técnica 72. Embrapa Arroz e Feijão, Santo Antônio de Goiás, GO.

Fortunato, A. A., Da Silva, W. L., and Rodrigues, F. A. 2014. Phenylpropanoid pathway is potentiated by silicon in the roots of banana plants during the infection process of Fusarium oxysporum f. sp. cubense. Phytopathology 104:597-603.

Hayasaka, T., Fujii, H., and Ishiguro, K. 2008. The role of silicon in preventing appressorial penetration by the rice blast fungus. Phytopathology 98: 1038-1044.

Hoagland, D. R., and Arnon, D. I. 1950. The water culture method for growing plant without soil. Calif. Agric. Exp. Stat. 347:1-32.

Kim, S. G., Kim, K. W., Park, E. W., and Choi, D. 2002. Silicon-induced cell wall fortification of rice leaves: A possible cellular mechanism of enhanced host resistance to blast. Phytopathology 92:1095-1103.

Koga, H., Zeyen, R. J., Bushnell, W. R., and Ahlstrand, G. G. 1988. Hypersensitive cell death, autofluorescence, and insoluble silicon accumulation in 
barley leaf epidermal cells under attack by Erysiphe graminis f. sp. hordei. Physiol. Mol. Plant Pathol. 32:395-409.

Korndörfer, G. H., Pereira, H. S., and Nolla, A. 2004. Análise de Silício: Solo, Planta e Fertilizante. Uberlândia, MG, Grupo de Pesquisa em Silício, ICIAG-Universidade Federal de Uberlândia (Boletim Técnico 1). Uberlandia. Minas Gerais State, Brazil.

Ma, J. F., Tamai, K., Ichii, M., and Wu, G. F. 2002. A rice mutant defective in Si uptake. Plant Physiol. 130:2111-2117.

Matsuo, T., and Hoshikama, K. 1993. Science of the Rice Plant Morphology. Food and Agriculture Policy Research Center, Tokyo, Japan.

Ou, S. H. 1985. Rice Diseases. Commonwealth Agricultural Bureaux, Slough, UK.

Rodrigues, F. A., Benhamou, N., Datnoff, L. E., Jones, J. B., and Bélanger, R. R. 2003. Ultrastructural and cytochemical aspects of silicon mediated rice blast resistance. Phytopathology 93:535-546.

Rodrigues, F. A., Jurick, W. M., II, Datnoff, L. E., Jones, J. B., and Rollins, J. A. 2005. Silicon influences cytological and molecular events in compatible and incompatible rice-Magnaporthe grisea interactions. Physiol. Mol. Plant Pathol. 66:144-159.

Rodrigues, F. A., McNally, D. J., Datnoff, L. E., Jones, J. B., Labbé, C., Benhamou, N., Menzies, J. G., and Bélanger, R. R. 2004. Silicon enhances the accumulation of diterpenoid phytoalexins in rice: A potential mechanism for blast resistance. Phytopathology 94:177-183.

Shaner, G., and Finney, R. E. 1980. The effect of nitrogen fertilization on the expression of slow-mildewing resistance in Knox wheat. Phytopathology 70:1183-1186.

Tatagiba, S. D., Rodrigues, F. A., Filippi, M. C. C., Silva, G. B., and Silva, L. C. 2014. Physiological responses of rice plants supplied with silicon to Monographella albescens infection. J. Phytopathol. 162:596-606.

Vermerris, W., and Nicholson, R. 2006. Phenolic Compound Biochemistry. Springer, Dordrecht, The Netherlands.

Weete, E. R. 1980. Lipid Biochemistry of Fungi and Other Organisms. Plenum Press, New York.

Yoshida, S., Ohnishi, Y., and Kitagishi, K. 1962. Histochemistry of Si in rice tissues. III. The presence of cuticle-silica double layer in the epidermal tissue. J. Soil Sci. Plant Nutr. 8:1-5.

Zeyen, R. J., Ahlstran, G. G., and Carver, T. L. W. 1993. X-ray microanalysis of frozen-hydrated, freeze-dried, and critical point dried leaf specimens: Determination of soluble and insoluble chemical elements at Erysiphe graminis epidermal cell papilla sites in barley isolines containing M1-o and $m l-o$ alleles. Can. J. Bot. 71:284-296. 